\title{
Hubungan Antara Pola Asuh Orangtua Dengan Kematangan Emosi Remaja
}

\author{
Farieska Fellasari, Yuliana Intan Lestari
}

\author{
Fakultas Psikologi Universitas Islam Negeri Sultan Syarif Kasim Riau \\ email:yuliana_intanlestari@yahoo.com
}

\begin{abstract}
Abstrak
Kematangan emosi dapat diperoleh melalui pola asuh yang diterima remaja ketika berada pada ruang lingkup keluarga. Penelitian ini bertujuan untuk melihat hubungan antara pola asuh orangtua dengan kematangan emosi. Pengambilan sampel pada penelitian ini menggunakan proportionate stratified random sampling dengan sampel 137 orang di SMA N 2 Tambang Kabupaten Kampar. Data dikumpulkan melalui empat skala, yaitu skala pola asuh orangtua authoritative, authoritarian dan permissive serta skala kematangan emosi. Data dianalisis dengan menggunakan analisis multiple regression dan bivariate correlate. Berdasarkan hasil analisis multiple regressiondiketahui bahwa terdapat hubungan antara pola asuh orangtua dengan kematangan emosi diperoleh $\mathrm{R}$ sebesar 0,454 pada taraf signifikansi $0,000(0,000 \leq 0,05)$. Hasil bivariate correlate dari masing-masing pola asuh yaitu terdapat hubungan antara pola asuh authoritative dengan kematangan emosi diperoleh $\mathrm{R}$ sebesar 0,420 dengan tarafsignifikansi $0,000(0,000 \leq 0,05)$ selanjutnya terdapat hubungan antara pola asuh authoritarian dengan kematangan emosi diperoleh $\mathrm{R}$ sebesar0,331 dengan tarafsignifikansi $0,000(0,000 \leq 0,05)$ dan tidak terdapat hubungan antara pola asuh permissive dengan kematangan emosi diperoleh $\mathrm{R}$ sebesar 0,149 dengan tarafsignifikan $0,082(0,082 \geq$ 0,05).
\end{abstract}

Kata kunci : pola asuh orangtua, kematangan emosi, remaja.

\section{Correlation Between Parenting Style and Emotional Maturity On Adolescence}

\begin{abstract}
Emotional Maturity can we get from parenting style which is accepted when adolescence there in their family. The purpose of this study was to find out correlation between parenting style and emotional maturity. The sample of this research used proportionate stratified random sampling with 137 students on Senior High School 2 Tambang Kabupaten Kampar. The data was collected through four scale, authoritative parenting style scale, authoritarian dan permissive and emotional maturity scale. The analysis methods used multiple regression and bivariate correlate. Based on the result from multiple regression was noted that there is correlation between parenting style and emotional maturity with $\mathrm{R}$ score 0,454 in significant value $0,000(0,000 \leq 0,05)$. Result of bivariate correlate from each of parenting style is there is correlation between authoritative parenting style with emotional maturity with $R$ score 0,420 with significant value $0,000(0,000 \leq 0,05)$. Next, there is correlation between authoritarian parenting style with emotional maturity with $R$ score 0,331 with significant value $0,000(0,000 \leq$ $0,05)$ and there is no correlation between permissive parenting style with emotional maturity with $R$ score 0,149 with significant value $0,082(0,082 \geq 0,05)$.
\end{abstract}

Keywords : parenting style, emotion maturity, adolescence

\section{Pendahuluan}

Remaja yang dalam bahasa latin disebut adolescence yang berarti "tumbuh" atau "tumbuh menjadi dewasa". Istilah remaja mempunyai arti yang lebih luas mencakup kematangan emosional, mental, sosial dan fisik, dimana masa remaja merupakan masa transisi dalam rentang kehidupan manusia yang menghubungkan masa kanak-kanak dan masa dewasa (Ali \& Asrori, 2010: 9). Masa remaja dimulai sekitar usia 10 hingga 13 tahun dan berakhir pada sekitar usia 18 hingga 22 tahun (Santrock, 2007: 20).

Masa remaja merupakan titik puncak emosionalitas, dimana terjadi perkembangan emosi yang tinggi, salah satunya terdapat pada pertumbuhan fisik remaja, terutama organ-organ seksual yang mempengaruhi berkembangnya emosi atau perasaan-perasaan dan dorongan-dorongan baru yang dialami sebelumnya, seperti perasaan cinta, rindu, dan keinginan untuk berkenalan lebih intim dengan lawan jenis (Yusuf, 2012: 197). 
Pada masa remaja, perkembangan fisik yang semakin nyata membuat remaja seringkali mengalami kesukaran dalam menyesuaikan diri dengan berbagai perubahan. Akibatnya, tidak jarang mereka cenderung menyendiri sehingga akan merasa terasing, merasa kurang perhatian dari orang lain, atau bahkan merasa tidak ada orang yang memperdulikannya. Kontrol terhadap dirinya sangat sulit dan mereka cepat marah dengan cara-cara yang kurang wajar untuk meyakinkan dunia sekitarnya. Perilaku ini terjadi karena adanya kecemasan terhadap dirinya sendiri sehingga muncul reaksi yang kadangkadang tidak wajar. Kecemasan yang ada pada diri remaja akan dapat menampilkan perilaku yang menunjukkan bahwa remaja tidak dapat mengontrol emosinya dengan baik. Bentuk perilaku kecemasan cenderung berbentuk perilaku negatif. Oleh karena itu, hendaknya seorang remaja telah mampu mencapai kematangan emosi pada masa ini (Ali \& Asrori, 2010: 68)

Murray (1997 : 1) mendefinisikan kematangan emosi sebagai suatu kondisi mencapai perkembangan pada diri individu dimana individu mampu mengarahkan dan mengendalikan emosi yang kuat agar dapat diterima oleh diri sendiri maupun orang lain. Menurut Murray (dalam Kapri \& Rani, 2014: $360)$ seorang remaja dikatakan telah memiliki kematangan emosi bila ia memiliki karakteristik kematangan emosi berikut (1) mudah mengalirkan cinta dan kasih sayang; (2) mampu untuk menghadapi kenyataan; (3) kemampuan menilai secara positif pengalaman hidup; (4) mampu berfikir positif mengenai diri pribadi; (5) penuh harapan; (6) ketertarikan untuk memberi; (7) kemampuan untuk belajar dari pengalaman; (8) kemampuan menangani permusuhan konstruktif; (9) berfikir terbuka.

Berdasarkan uraian di atas, maka dapat dikatakan apabila remaja memiliki kematangan emosi dengan baik, maka ia akan mampu berperilaku sesuai dengan karakteristik kematangan emosi tersebut. Sedangkan, remaja yang tidak memiliki kematangan emosi akan melakukan perilaku tidak sesuai dengan karakteristik dari kematangan emosi itu sendiri. Intinya remaja yang memiliki kematangan emosi akan mampu melakukan kontrol terhadap emosinya, hal ini sesuai dengan pendapat De Claire (dalam Paramithasari \& Alfian, 2012: 3) yang menyatakan remaja yang lebih matang secara emosional masih akan mengalami kesedihan, marah, dan takut tetapi mereka akan lebih mampu menenangkan diri mereka sendiri, bangkit dari kemurungan dan dapat melanjutkan kegiatan-kegiatan produktif dengan baik.

Pembentukan kematangan emosi tidak lepas dari peranan pola asuh orangtua, karena orangtua adalah orang pertama yang memiliki peranan dalam mengatur dan mendidik seorangremaja untuk memperoleh kematangan emosi yang baik. Hurlock (1980: 115) mengatakan bahwa masalah emosi yang terjadi pada remaja dapat diakibatkan salah satunya oleh pola asuh orangtua.

Baumrind (dalam Yusuf, 2012: 51) mendefinisikan pola asuh sebagai pola sikap atau perlakuan orangtua terhadap remaja yang masing-masing mempunyai pengaruh tersendiri terhadap perilaku remaja antara lain terhadap kompetensi emosional, sosial, dan intelektual. Menurut Baumrind (dalam Yusuf, 2012: 51) terdapat tiga pola asuh orangtua terhadap remaja dimana masing-masing memiliki kontribusi yang penting dalam pembentukan karakter anak. Pola asuh tersebut yaitu authoritative, authoritarian dan permissive.

Orangtua yang authoritative akan memiliki sikap "acceptance" dan kontrol yang tinggi terhadap remaja, bersikap responsif terhadap kebutuhan remaja, mendorong remaja untuk menyatakan pendapat atau pertanyaan dan memberikan penjelasan tentang dampak perbuatan yang baik dan yang buruk (Baumrind dalam Yusuf, 2012: 52).

Pola asuh orangtua yang authoritative akan berdampak kepada kematangan emosi remaja, hal ini dikarenakan remaja yang diasuh dengan pola asuh authoritative akan memiliki kemampuan dapat menghindari permusuhan karena pola asuh orangtua yang selalu menjelaskan mengenai dampak perbuatan baik dan buruk kepada dirinya, remaja mudah mengalirkan cinta dan kasih sayang karena sikap responsif dan "acceptance" yang diterima remaja dari kedua orangtuanya, serta remaja mampu berfikir positif mengenai diri pribadinya. Hal ini sesuai dengan penelitian Baumrind (1991: 62) yang mengatakan bahwa remaja yang diasuh menggunakan pola asuh authoritative akan memiliki sikap optimis, berprestasi di sekolah, bertanggung jawab, serta lebih berkompeten dibandingkan teman-temannya. Sementara itu, orangtua yang authoritarian akan memiliki sikap "acceptance" yang rendah namun kontrolnya tinggi terhadap remaja, suka menghukum secara fisik, bersifat mengomando, bersikap kaku (keras), dan cenderung emosional serta bersikap menolak (Baumrind dalam Yusuf, 2012: 52).

Pola asuh authoritarian yang diterapkan orangtua akan berdampak kurang baik pada kemampuan remaja dalam melakukan pengontrolan emosi. Hal ini dikarenakan, pola asuh yang diterima remaja di rumah cenderung emosional dan keras sehingga remaja akan merasa tidak nyaman, akan mengalami tekanan, mudah mengalami stres, memiliki sikap pencemas, emosi yang tidak stabil, penakut, pendiam serta tertutup, dan remaja yang diasuh menggunakan pola asuh authoritarian lebih mudah terpengaruh untuk melakukan 
pelanggaran norma sehingga tingkat kematangan emosi remaja sangatlah rendah. Hal ini sesuai dengan penelitian Baumrind (1991: 62) yang mengatakan bahwa remaja yang diasuh menggunakan pola asuh authoritarian akan susah dalam mengontrol emosinya, kurang memiliki prestasi di sekolah, dan cenderung terjerumus ke dalam perilaku negatif.

Selain itu, remaja yang diasuh dengan gaya pengasuhan authoritarian punya potensi untuk tidak mudah mengalirkan cinta serta kasih sayang dikarenakan sikap kaku yang diterima remaja dari kedua orangtua. Remaja juga kurang dapat mengatur hidupnya untuk masa depan karena masa depan remaja berada ditangan kedua orangtuaya.

Orangtua yang permissive akan memiliki sikap "acceptance" yang tinggi namun kontrolnya rendah terhadap remaja dan memberikan kebebasan kepada remaja untuk menyatakan dorongan atau keinginannya (Baumrind dalam Yusuf, 2012: 52).

Pola asuh permissive yang diterapkan orangtua akan membuat remaja memiliki kontrol emosi yang rendah dan kecenderungan memiliki perilaku agresif, hal ini dikarenakan kontrol perilaku orangtua yang rendah terhadap remaja dan membuat remaja tidak memiliki rasa takut akan melanggar peraturan. Sehingga akan berdampak seringnya remaja mengalami permusuhan baik itu di sekolah, di rumah maupun di lingkungan masyarakat.

Pola asuh permissive yang diterapkan orangtua juga membuat remaja menjadi tidak patuh, manja, kurang mandiri dan mau menang sendiri. Sehingga, jika remaja dihadapkan pada kenyataan yang tidak sesuai dengan keinginannya, remaja akan mudah memberontak, menangis dan meratapi kenyataan tersebut tanpa dapat menerimanya. Hal ini sesuai dengan penelitian Baumrind (1991: 63 ) yang mengatakan bahwa remaja yang diasuh menggunakan pola asuh yang permissive akan memiliki sikap suka memberontak, memiliki rasa pengendalian diri yang rendah, tidak jelas arah hidupnya dan kurang percaya diri.

Berdasarkan ketiga pola asuh orangtua, yaitu pola asuh orangtua yang authoritative, authoritarian, dan permissive. Pola asuh yang authoritative merupakan pola asuh yang dapat menimbulkan sikap kematangan emosi pada remaja sedangkan pola asuh authoritarian dan permissive merupakan pola asuh yang kurang dapat menimbulkan sikap kematangan emosi pada remaja.

Dengan demikian dapat dikatakan bahwa pola asuh yang diterapkan orangtua di rumah akan berdampak kepada perilaku yang ditimbulkan remaja. Sehingga kondisi ini akan mendorong tumbuh dan berkembangnya aspek kematangan emosi remaja. Kematangan emosi dapat diperoleh jika keluarga memberi- kan kasih sayang kepada remaja. Dengan kasih sayang, remaja akan merasa nyaman dan jauh dari perilaku negatif. Sebaliknya, ketidakmatangan emosi terjadi jika orangtua bersikap acuh tak acuh dan memaksakan kehendaknya pada remaja. Hal tersebut akan membuat remaja merasa tertekan dan menjadi mudah marah.

Berdasarkan uraian yang peneliti kemukakan di atas maka "Ada Hubungan Antara Pola Asuh Orangtua Dengan Kematangan Emosi". Secara rinci hipotesis dalam penelitian ini adalah sebagai berikut (1) Ada hubungan positif antara pola asuh orangtua yang authoritative dengan kematangan emosi remaja; (2) Ada hubungan negatif antara pola asuh orangtua yang authoritarian dengan kematangan emosi remaja; (3) Ada hubungan negatif antara pola asuh orangtua yang permissive dengan kematangan emosi remaja.

\section{Metode}

\section{Subjek}

Subjek dalam penelitian ini adalah remaja yang berada pada Sekolah Menengah Atas (SMA) Negeri 2 Tambang, Kabupaten Kampar dengan jumlah 137 siswa. Teknik pengambilan sampel yang digunakan adalah proportionate stratified random sampling. Proportionate stratified random sampling adalah teknik untuk menentukan sampel bila populasi mempunyai anggota yang berstrata secara proporsional (Sugiyono, 2009: 82).

Pelaksanaan proportionate stratified random sampling dalam penelitian ini adalah dengan cara menetapkan jumlah sampel berdasarkan strata kelas terlebih dahulu kemudian melakukan random untuk memilih kelas yang akan dijadikan sampel penelitian.

Adapun rincian subjek penelitian yaitu 55 subjek berasal dari kelas $X$ dimana 19 subjek berasal dari kelas X MIA1 dan 36 subjek berasal dari kelas X IIS1, 41 subjek berasal dari kelas XI dimana 29 subjek berasal dari kelas XI IIS1 dan 12 subjek berasal dari kelas XI IIS2 serta 41 subjek berasal dari kelas XII dimana 11 subjek berasal dari kelas XII IPA2 dan 30 subjek berasal dari kelas XII IPS1.

\section{Pengukuran}

Metode pengumpulan data adalah bagian instrumen pengumpulan data yang menentukan berhasil atau tidaknya suatu penelitian (Bungin, 2005: 119). Peneliti menggunakan metode pengumpulan data dengan skala dikarenakan penyajiannya praktis dan cara kerjanya mudah sehingga dapat dikerjakan subjek dalam waktu yang relatif singkat (Azwar, 2010: 3).

Skala pada penelitian ini terdiri atas empat skala, yaitu skala pola asuh orangtua authoritative, skala pola asuh orangtua 
authoritarian, dan skala pola asuh orangtua permissive, serta skala kematangan emosi. Skala disusun dalam bentuk skala Likert dengan empat alternatif jawaban yaitu (SS) Untuk jawaban Sangat Sesuai, (S) Untuk jawaban Sesuai. (TS) Untuk jawaban Tidak Sesuai, (STS) Untuk jawaban Sangat Tidak Sesuai.

\section{Skala Pola Asuh orangtua authoritative}

Skala pola asuh orangtua authoritative berjumlah 40 aitem pernyataan, yang disusun oleh peneliti berdasarkan aspek teori Baumrind (dalam Yusuf, 2012: 52), yaitu sikap "acceptance" dan kontrolnya tinggi, bersikap responsif terhadap kebutuhan remaja, mendorong remaja untuk menyatakan pendapat dan pertanyaan, dan memberikan penjelasan tentang dampak perbuatan yang baik dan yang buruk.

\section{Skala Pola Asuh Orangtua Authoritarian}

Skala pola asuh orangtua authoritarian berjumlah 40 aitem pernyataan, yang disusun oleh peneliti berdasarkan aspek teori Baumrind (dalam Yusuf, 2012: 52), yaitu sikap "acceptance" rendah namun kontrolnya tinggi, suka menghukum secara fisik, bersikap mengomando, bersikap kaku, dan cenderung emosional dan bersikap menolak.

\section{Skala Pola Asuh Orangtua Permissive}

Skala pola asuh orangtua permissive berjumlah 20 aitem pernyataan, yang disusun oleh peneliti berdasarkan aspek teori Baumrind (dalam Yusuf, 2012: 52), yaitu sikap "acceptance" tinggi namun kontrolnya rendah dan memberikan kebebasan kepada remaja untuk menyatakan dorongan atau keinginannya.

\section{Skala Kematangan Emosi}

Skala kematangan emosi berjumlah 54 aitem pernyataan, yang disusun oleh peneliti berdasarkan aspek teori Murray (dalam Kapri \& Rani, 2014: 360), yaitu mudah mengalirkan cinta dan kasih sayang, mampu untuk menghadapi kenyataan, kemampuan menilai secara positif pengalaman hidup, mampu berfikir positif mengenai diri pribadi, penuh harapan, ketertarikan untuk memberi, kemampuan untuk belajar dari pengalaman, kemampuan menangani permusuhan secara kontruktif, dan berfikir terbuka.

\section{Analisis data}

Teknik analisis data yang digunakan dalam penelitian ini adalah analisis multiple regression untuk mengetahui hubungan antara pola asuh orangtua dengan kematangan emosi. Teknik analisis data yang digunakan untuk mengetahui hubungan antara ketiga pola asuh yaitu pola asuh orangtua authoritative (X1), pola asuh orangtua authoritarian
(X2) dan pola asuh orangtua permissive (X3) dengan kematangan emosi adalah teknik simple regression. Penghitungan analisis dibantu dengan menggunakan SPSS (Statistics forProducts and Services Solution) versi 17 for windows

\section{Hasil}

\section{Deskripsi Subjek}

Sesuai dengan judul penelitian ini, yaitu hubungan pola asuh orangtua dengan kematangan emosi remaja, maka subjek dalam penelitian ini ialah siswa Sekolah Menengah Atas (SMA) Negeri 2 Tambang, Kampar.subjek penelitian yang berjenis kelamin laki-laki sebesar $48,2 \%$ (66 orang) dan perempuan sebesar 51,8 \% (71 orang). Kemudian berdasarkan usia subjek penelitian, subjek yang berusia 14-15 tahun yang termasuk kategori remaja awal (Hurlock, 1980: 206) sebesar $16 \%$ (22 orang) dan subjek yang berusia 16-18 tahun yang termasuk kategori remaja akhir (Hurlock, 1980: 206) sebesar 84\% (115 orang).

\section{Hasil Uji Asumsi}

Uji asumsi yang akan dilakukan dalam penelitian ini adalah uji normalitas. Uji normalitas digunakan sebagai syarat dari analisis data multiple regression dan bivariate regression yang akan dilakukan dalam penelitian ini. Pengujian normalitas menggunakan bantuan SPSS (statistics for prodcuct and service solution) versi 17 for windows.Adapun cara yang digunakan untuk melihat sebaran data tersebut normal atau tidak normal pada penelitian ini adalah dengan menggunakan one sample kolmogrov-smirnov dengan signifikansi $p \geq$ 0,05 (Usman \& Akbar, 2009: 106).

Uji normalitas dalam penelitian ini dilakukan pada dua variabel yaitu variabel pola asuh orangtua yang terdiri atas pola asuh orangtua authoritative, authoritarian dan permissive serta variabel kematangan emosi. Dari hasil uji normalitas, diketahui signifikansi (asymp sig) pola asuh authoritative sebesar 0,554 , signifikansi (asymp sig)pola asuh authoritarian sebesar 0,756, dansignifikansi (asymp sig) pola asuh permissive sebesar 0,139 sedangkan signifikansi (asymp sig) pada kematangan emosi sebesar 0,538. Secara keseluruhan semua variable dapat dikatakan berdistribusi normal.

Uji validitas dari 40 aitem skala pola asuh orangtua authoritative yang diujicobakan, terdapat 26 aitem yang valid dengankoefisien korelasi aitem total yang berkisar antara $0,306-0,685$. Pada variabel pola asuh orangtua authoritarian terdapat 40 aitem yang diujicobakan, terdapat 17 aitem yang valid dengan koefisien korelasi aitem total berkisar antara $0,324-0,657$. 
Pada variabel pola asuh orangtuapermissive terdapat 20 aitem yang diujicobakan, terdapat 10 aitem yang valid dengan koefisien korelasi aitem total berkisar antara 0,301 0,582 . Pada variabel kematangan emosi terdapat 54 aitem yang diujicobakan validitasnya dan terdapat 37 aitem yang valid dengan koefisien korelasi aitem total berkisar antara $0,300-0,700$.

Berdasarkan hasil uji reliabilitas terhadap aitem yang valid pada skala pola asuh orangtua authoritative (X1) diperoleh koefisien reliabilitas sebesar 0,889 . Pada pola asuh orangtua authoritarian (X2) diperoleh koefisien reliabilitas sebesar 0,836 dan pada pola asuh orangtua permissive (X3) diperoleh koefisien reliablitas sebesar 0,747 . Sedangkan pada kematangan emosi $(Y)$ diperoleh koefisien reliabilitas sebesar 0,924 . Secara keseluruhan keempat skala dapat dikatakan reliabel.

\section{Hasil Uji Hipotesis}

Penelitian ini memiliki dua hipotesis yang terdiri atas hipotesis mayor dan minor. Hipotesis mayor yaitu ada hubungan antara pola asuh orangtua $(X)$ dengan kematangan emosi $(Y)$ yang dianalisis menggunakan analisis multiple regression dan hipotesis minor yang merupakan bagian-bagian dari pola asuh orangtua, terdiri atas pola asuh orangtua authoritative (X1), authoritarian (X2) dan permissive (X3) yang dianalisis menggunakan bivariate regression.Analisis data dibantu dengan program SPSS 17 for windows.

Hasil analisis multiple regression terhadap pola asuh orangtua $(\mathrm{X})$ dengan kematangan emosi $(Y)$ menunjukkan hasilanalisis regresi $(R)$ sebesar 0,454 dengan $F$ hitung sebesar 11.519 pada taraf signifikansi 0,000 , karena probabilitas $(p)$ yaitu 0,000 lebih kecil dari $0,05(0,000 \leq 0,05)$. Hasil ini menunjukkan bahwa pola asuh orangtua yang terdiri atas pola asuh authoritative, authoritarian dan permissive memiliki hubungan dengan kematangan emosi, maka hipotesis yang diajukanditerima.

Secara rinci pola asuh orangtua terbagi menjadi tiga macam, yaitu pola asuh orangtua authoritative, authoritarian, dan permissive. Dari ketiga pola asuh orangtua tersebut hubungannya dengan kematangan emosi, diketahui bahwa untuk pola asuh authoritative (X1) diperoleh hasilanalisisregresi $(R)$ sebesar 0,420 dengan $F$ hitungsebesar 28,841 padataraf signifikansi sebesar 0,000, karena probabilitas (p) 0,000 lebih kecil dari $0,05(0,000 \leq 0,05)$, hal ini berarti bahwaterdapat hubungan positif antara pola asuh orangtuaauthoritative dengan kematangan emosi remaja sehingga hipotesis yang diajukan diterima. Dapat diartikan bahwa orangtua yang menerapkan pola asuhauthoritative kepada remaja akan memilikiremaja yang dapat mengendalikan emosinya

Pada pola asuh authoritarian (X2) diperoleh hasilanalisisregresi (R) sebesar 0,331 dengan $F$ hitungsebesar 16,656 padataraf signifikansi sebesar 0,000 , karena probabilitas (p) 0,000 lebih kecil dari 0,05 (0,000 $\leq$ $0,05)$, hal ini berarti bahwaterdapat hubungan negatif antara pola asuh orangtua authoritarian dengan kematangan emosi remaja sehingga hipotesis yang diajukan diterima. Dapat diartikan bahwa orangtua yang menerapkan pola asuhauthoritarian kepada remaja akanmemilikiremaja yang kurang dapat mengendalikan emosinya.

Sementara itu pola asuh permissive (X3) diperoleh hasilanalisisregresi (R) sebesar 0,149 dengan $F$ hitungsebesar 3,074 padataraf signifikansi sebesar 0,082, karena probabilitas (p) 0,082 lebih besar dari 0,05 $(0,082 \geq 0,05)$, hal ini berarti terdapat hubungan positif antara pola asuh orangtua permissive dengan kematangan emosi remaja sehingga hipotesis yang diajukan ditolak. Dapat diartikan bahwa orangtua yang menerapkan pola asuhpermissive kepada remajaakan memiliki remaja yang dapat mengendalikan emosinya.

\section{Pembahasan}

Hasil analisis multiple regression pada penelitian ini menghasilkan bahwa terdapat hubungan antara pola asuh orangtua dengan kematangan emosi remaja. Pola asuh yang ditetapkan orangtua di rumah, baik itu pola asuh authoritative, authoritarian dan permissive memiliki hubungan dengan tingkat kematangan emosi remaja. Penemuan ini mendukung penelitian yang dilakukan oleh Miller (dalam Rahman, 2008: 78) bahwa ketika orangtua terlibat dalam pengasuhan remaja dan menerapkan disiplin yang cukup tinggi akan mengurangi kecenderungan remaja berperilaku eksternalisasi (marah, bandel, berperilaku menyimpang).

Hal yang sama juga diungkapkan Jadhav (2010: 35) bahwa terdapat hubungan yang signifikan antara lingkungan keluarga dengan kematangan emosi baik itu pada remaja laki-laki maupun perempuan, remaja yang bersekolah di desa maupun di kota, status social ekonomi tinggi maupun rendah.

Pola asuh orangtua terbagi menjadi tiga, yaitu pola asuh authoritative, pola asuh authoritarian dan pola asuh permissive. Hasil uji hipotesis menghasilkan bahwa, terdapat hubungan positif antara pola asuh authoritative dengan kematangan emosi remaja yang artinya orangtua yang menerapkan pola asuh authoritative dalam mendidik remaja di rumah akanmenimbulkan kematangan emosipada diri remaja. 
$\mathrm{Hal}$ ini sesuai dengan penelitian $\mathrm{Hu}-$ ver, Otten, Vriesdan Engels mengenaipersonality and parenting style in parent of adolescents (2010: 399) yang menghasilkan bahwa orangtua authoritative akan memiliki tingkat kestabilan emosi yang baik sehingga dapat mengontrol perilaku remaja mereka dan mengarahkan kepada perilaku yang baik.

Jackson (dalamHuver, Otten, Vries, dan Engels, 2010: 399) mengatakan bahwa orangtua authoritative telah terbukti memiliki pengaruh yang baik pada perkembangan remaja, termasuk perkembangan emosi remaja. Hal ini senada dengan teori Baumrind (dalam Marini \& Indriani, 2005: 50) bahwa orangtua yang menjalankan pola asuh authoritative dalam mendidik remaja, akan memiliki perkembangan emosional, sosial dan kognitif yang positif.

Hasil uji hipotesis pada pola asuh authoritarian menghasilkan bahwa terdapat hubungan negatif antara pola asuh authoritarian dengan kematangan emosi remaja yang artinya apabila orangtua menerapkan pola asuh authoritarian kepada remaja, maka akan memiliki remaja yang kurang dapat mengendalikan emosinya. Hal ini sesuai dengan penelitian yang dilakukan oleh Knafo (2003: 199) orangtua yang menggunakan pola asuh authoritarian lebih mengharapkan remaja mereka memiliki kekuatan yang tinggi dan mengikuti setiap perkataan mereka, sehingga remaja yang memperoleh pola asuh authoritarian cenderung memiliki perilaku negatif kepada orang lain dikarenakan tuntutan dari orangtua yang mengharuskan mereka memiliki kekuatan.

Penelitian selanjutnya oleh Hoeve, Blokland, dan Dubas (2008: 233) mengenai trajectories of delinquency and parening style, menghasilkan bahwa remaja yang berperilaku delinquency lebih dominan berasal dari keluarga yang menggunakan pola asuh authoritarian. Hal ini senada dengan penelitian yang dilakukan oleh Lubis (2011: 4) mengenai pola asuh orangtua dan perilaku delinquency, yang menghasilkan bahwa kebanyakan perilaku delinquency dilakukan oleh remaja yang memperoleh pola asuh authoritarian ketika di rumah. Perilaku delinquency merupakan perilaku yang berlandaskan emosi dan hal inidapat memperlihatkan bahwa remaja tidak memiliki kematangan emosi yang seharusnya ada pada masa ini.

Hasil uji hipotesis pada pola asuh permissive dengan kematangan emosi menghasilkan bahwa terdapat hubungan positif antara pola asuh permissive dengan kematangan emosi remaja yang artinya bahwa apabila orangtua menerapkan pola asuh permissive kepada remaja, maka akan dapat menimbulkan kematangan emosi remaja. Hal ini senada dengan penelitian yang dilakukan oleh Jadhav (2010: 35) bahwa pola asuh permissive yang diterima remaja memiliki hubungan dengan kematangan emosi remaja.

Penelitian yang dilakukan oleh Tam, Chong, Kadirvelu \& Khoo (2012: 22) menghasilkan bahwa pola asuh permissive yang diterima remaja ketika di rumah akan dapat mendorong kemandirian dan kemajuan pada diri remaja. Hal ini dikarenakan, kurangnya pengawasan dan kasih sayang orangtua kepada remaja membuat remaja melakukan segala sesuatunya sesuai dengan keinginannya dan remaja juga lebih bertanggung jawab terhadap keputusan yang diambilnya.

$\mathrm{Hal}$ ini sesuai dengan penelitian yang dilakukan Respati, Yulianto \& Widiana (2006: 136) yang menghasilkan bahwa pola asuh permissive yang digunakan orangtua akan dapat meningkatkan kemandirian serta kontrol diri remaja. Berbeda dengan penelitian yang dilakukan Huver, Otten, Vriesdan Engels mengenai personality and parenting style in parent of adolescents (2010: 401) yang menghasilkan bahwa meskipun orangtua permissive memiliki kestabilan emosi yang cukup stabil dalam mendidik, tetapi hal tersebut tidak memiliki pengaruh terhadap kepribadian remaja.

Selain menerapkan ketiga pola asuh di atas, menjadi orang tua juga perlu menerapkan spiritual parenting berarti memprioritaskan kehidupan diri kita sendiri, dimana Tuhan berada pada urutan tertinggi, sehingga jiwa orangtua dan jiwa anak menjadi sangat penting. Spiritual parenting mengimplikasikan bahwasanya orang tua tidak hanya hadir untuk anak mereka, namun juga untuk diri mereka sendiri (Hart, 2004). Seseorang yang lebih dulu mengakui diri sendiri sebagai makhluk spiritual, maka seseorang itu dapat mendidik anak-anak dengan menyadari bahwa anak-anak adalah individu yang benar-benar berketuhanan (Doe, 1998).

Spiritual parenting menurut Jahja (2011) adalah salah satu bentuk pola asuh yang dapat diterapkan orangtua untuk mengisi jiwa remaja-remaja menjadi individu yang hangat dan bersemangat dengan nilai-nilai spiritual. Remaja adalah insan spiritual, begitu pula dengan orangtua. Bersatunya insan spiritual semakin membuat kehidupan keluarga menjadi tentram.

Cara paling awal ialah membangkitkan rasa ingin tahu remaja terhadap agamanya sendiri. Hal ini dapat dilakukan dengan memberikan contoh pada remaja bagaimana orangtua beribadah, sehingga remaja akan tertarik untuk mengetahui agama lebih lanjut. Orang tua juga mampu memenuhi semua kebutuhan emosi dan sosial remaja, menjadi panutan yang baik dihadapan remaja, menjadi orangtua yang spiritual dengan memimpin doa saat melakukan berbagai aktivitas bersa 
ma, orangtua tidak malu untuk meminta maaf kepada remaja jika mereka melakukan kesalahan, mengajak remaja mengunjungi keluarga atau tetangga yang tertimpa musibah, dan lain sebagainya.

Berdasarkan uraian di atas mengenai pola asuh authoritative, authoritarian dan permissive, pola asuh authoritative lebih membawa dampak positif bagi perkembangan remaja. Remaja yang memperoleh pola asuh authoritative dari orangtuanya akan memiliki perkembangan emosional yang positif, bersikap bersahabat, memiliki rasa percaya diri, mampu mengendalikan diri, bersikap sopan, mau bekerja sama, berprestasi di sekolah, bertanggung jawab, dan lebih berkompeten dibandingkan teman-temannya (Baumrind, 1991: 62).

\section{Kesimpulan}

Berdasarkan hasil analisis dan pembahasan dalam penelitian ini, dapat ditarik kesimpulan sebagai berikut:a) Pola asuh orangtua berhubungan dengan kematangan emosi remaja, dalam artian bahwa pola asuh yang diterapkan oleh orangtua baik itu authoritative, authoritarian dan permissive secara bersama-sama berkaitan dengan kematangan emosi remaja. b) Penerapan metode pengasuhan authoritative di dalam keluarga memiliki hubungan positif dengan pembentukan kematangan emosi pada remaja, c) Penerapan metode pengasuhan authoritarian di dalam keluarga memiliki hubungan negatif dengan pembentukan kematangan emosi remaja dan d) Penerapan metode pengasuhan orangtua yang permissive memiliki hubungan positif dengan pembentukan kematangan emosi remaja.

\section{Daftar pustaka}

Ali, M \& Asrori, M. (2010). Psikologi Remaja, Perkembangan Peserta Didik. Jakarta: Bumi Aksara.

Azwar, S. (2009). Dasar-Dasar Psikometri. Yogyakarta: Pustaka Pelajar.

Baumrind, D. (1991). The Influence Of Parenting Style On Adolescent Competence And Subtance Use. Journal Of Early Adolescence. 11. 1. 59-95.

Bungin, B. (2005. Metodologi Penelitian Kuantitatif. Jakarta: Kencana Media Groub.

Hoeve, M., Blokland, A., \&Dubas, J. (2008). Trajectories Of Delinquency And Parenting Style. J Abnorm Child Psychol. 36. 223-235.

Hurlock, E. B. (1980). Psikologi Perkembangan Edisi Kelima. Jakarta:
Erlangga.

Huver, R., Otten, R., Vries, H., \& Engels, R. (2010). Personality And Parenting Style In Parent Of Adolescent. Journal Of Adolescence. 33. 395-402.

Jadhav, N. S. (2010). Relationship Between Home Environment \& Emotional Maturity Of College Going Student Of Belgaum District. International Research Journal. 1. 34-36.

Jahja, Yudrik. 2011. Psikologi Perkembangan. Jakarta: Kencana Prenada Media Group

Kapri, U. C. Rani, N. (2014). Emotional Maturity: Characteristics And Levels. International Journal Of Technological Exploration And Leasrning. 3. 1. 359361.

Lubis, R. (2011). Pola Asuh Orang Tua Dan Perilaku Delinkuensi. Turats. 7. 2. 1-7.

Marini \& Andriani. (2005). Perbedaan Asertivitas Remaja Ditinjau Dari Pola Asuh Orang Tua. Psikologia. 1. 2. 4651.

Murray. (1997).Emotional Maturity. http:// www. sonic.net drmurraymaturity.htm!. (Diakses Tanggl 26 Maret 2014).

Paramitasari, R \& Alfian, I. (2012). Hubungan Antara Kematangan Emosi Dengan Kecenderungan Memaafkan Pada Remaja Akhir. Jurnal Psikologi Pendidikan Dan Perkembangan. 1. 02. 1-7.

Rahman, I. (2008). Hubungan Antara Persepsi Terhadap Pola Asuh Demokratis Ayah Dan Ibu Dengan Perilaku Disiplin Remaja. Lentera Pendidikan. 11. 1. 69-82.

Respati, W., Yulianto, A., Widiana, N. (2006). Perbedaan Konsep Diri Antara Remaja Akhir Yang Mempersepsi Pola Asuh Orang Tua Authoritarian, Permissive, Dan Authoritative. Jurnal Psikologi. 4. 2. 119-138.

Santrock, J. (2007). Remaja, Edisi 11 Jilid 1. Jakarta: Erlangga.

Sugiyono. (2009). Metode Penelitian Kuantitatif Kualitatif Dan R \& D. Bandung: Alfabeta.

Tam, C., Chong, A., Kadirvelu, A., Khoo, Y. (2012). Parenting Style and Self Efficacy Of Adolescent: Malaysian Scenario. Journal Of Human Social Science. 12. 18-25.

Usman, H., Akbar, P. (2009). Pengantar Statistik, Edisi Kedua. Jakarta: Bumi Aksara.

Yusuf, S. (2012). Psikologi Perkembangan Anak \& Remaja. Bandung: Remaja Rosda Karya 